\author{
TOMASZ KOMORNICKI
}

IGiPZ PAN, Warszawa

\title{
Eksport w ujęciu regionalnym jako miernik rozwoju przemysłu
}

Wiele tradycyjnych mierników stosowanych w geografii przemysłu straciło w okresie transformacji systemowej swoje znaczenie. W przypadku innych drastycznie zmalała osiagalność danych pierwotnych. Przestrzeń przemysłowa badana w oparciu o wielkość zatrudnienia w drugim sektorze gospodarki uległa w Polsce w tym okresie znacznemu ograniczeniu (Gierańczyk, Stańczyk 2001). Jednocześnie w miejsce miar ilościowych w ocenie potencjału przemysłowego coraz większego znaczenia nabierać zaczęły wskaźniki jakościowe. Obrazują one zarówno strukturę produkcji (udział branż zaawansowanych technologicznie), jak i sytuację rynkową poszczególnych przedsiębiorstw (obroty, rentowność itd.). Proces kurczenia się przestrzeni industrialnej nabiera w tym kontekście innego wymiaru i nie jest aż tak jednoznaczny (z całą pewnością możemy jedynie mówić o kurczeniu się tradycyjnej przestrzeni przemysłowej).

$\mathrm{W}$ tych warunkach jednym z istotnych elementów charakteryzujących pośrednio sferę produkcyjną stał się eksport. Sprzedaż towarów na rynkach zagranicznych dowodzi najczęściej ich relatywnie wysokiej konkurencyjności. Jest przejawem zachodzącej integracji ekonomicznej. Uważa się, że dziedziną, która ma największy wpływ na zaawansowanie procesów globalizacji w Polsce, jest obecnie właśnie handel międzynarodowy (Wnorowski 2002). Trzeba jednak pamiętać, że handel zagraniczny stracił w warunkach globalizacji swoją dotychczasowa naturę. W miejsce wymiany dóbr przez przedsiębiorstwa z różnych krajów stał się wielokrotną wymianą komponentów i półproduktów w ramach sieci przedsiębiorstw ponad granicami państw (Stryjakiewicz 2002).

Za podjęciem tematyki przestrzennego wymiaru eksportu przemawia również fakt, że dane o wielkości wywozu są w chwili obecnej bardziej wiarygodne niż dane dotyczące samej produkcji. Pochodzą one ze zbieranych na granicach państwa druków SAD (są opracowywane przez centrum informatyki handlu zagranicznego w Warszawie) i stanowią pełny obraz statystyczny zagadnienia. Wykorzystując te materiały dla celów geografii przemysłu należy jednak pamiętać, że agreguje się je wg siedziby eksportera, nie producenta, a niektóre podmioty gospodarcze w Polsce zajmują się reeksportem towarów wcześniej importowanych. Nieścisłości związane z wymienionymi ograniczeniami w ogromnej mierze koncentrują się jednak w Warszawie i kilku innych aglomeracjach (skupiających firmy eksportowe, w tym byłe Centrale Handlu Zagranicznego). Na pozostałym obszarze kraju wartości eksportu w znacznym stopniu odpowiadają wartościom produkcji na eksport. 
Celem niniejszego opracowania jest prezentacja możliwych do wykorzystania w geografii przemysłu mierników bazujących na wielkości eksportu. Uzupełnieniem są krótkie omówienia rozkładów przestrzennych poszczególnych mierników na terenie Polski w roku 2000. Na ich podstawie podjęto próbę oceny wzajemnej relacji ,,przestrzeni przemysłowej” i ,przestrzeni eksportowej" Polski.

Liczba opracowań dotyczących wewnętrznej struktury regionalnej polskiego handlu zagranicznego jest w literaturze bardzo niewielka. Do pierwszych prac wykorzystujących materiały Centrum Informatyki Handlu Zagranicznego (CIHZ) zaliczyć należy prace prowadzone w ramach projektu West - Ost Axe przez Institut für Landerkunde w Lipsku (Rossner, Anisimowa... 1998). Strukturę wymiany handlowej Polski południowej poddano tam analizie pod kątem powiązań z Niemcami oraz Ukrainą. Dane CIHZ w swoich opracowaniach wykorzystywał też T. Komornicki (2000) badając strukturę geograficzną wymiany poszczególnych dawnych województw, strukturę kierunkową handlu zagranicznego według korytarzy transportowych.

Analizą polskiego handlu zagranicznego na poziomie regionalnym zajmował się również H. Rogacki (2001). Rozpatrywał on zagadnienie z punktu widzenia ,triady Ullmana”. Wyróżnił sześć podstawowych czynników kształtujących aktywność importową i eksportową polskich województw: (a) strukturę przemysłu i jego nowoczesność, (b) napływ kapitału, (c) położenie województwa i kraju partnera, (d) potencjał i poziom gospodarczy partnera, (e) stabilność gospodarczą i polityczną oraz (e) bariery własne i bariery partnera. Wartości obrotów handlu zagranicznego w latach 1994 i 1998 autor odnosił do liczby ludności, PKB, liczby podmiotów gospodarczych, liczby pracujących w przemyśle i budownictwie i produkcji przemysłowej. Obliczył też wskaźnik dywersyfikacji, który zdecydowanie najwyższy okazał się w przypadku województw mazowieckiego, śląskiego i małopolskiego, a najmniejszy dla zdominowanych przez obroty z Niemcami - lubuskiego, opolskiego i wielkopolskiego.

Struktura towarowa polskiego handlu zagranicznego na poziomie wojewódzkim była ponadto przedmiotem badań J. Grabowieckiego (2001). Analizował on sytuację województwa podlaskiego na tle wymiany prowadzonej przez inne województwa. Dokonał prostego podziału województw na cztery grupy na podstawie udziału w handlu zagranicznym. Do pierwszej (największa rola w polskich obrotach) zaliczył województwa mazowieckie i śląskie; do drugiej (średnie znaczenie) pomorskie, wielkopolskie i dolnośląskie. W grupie ostatniej, która w minimalnym stopniu uczestniczy w wymianie, znalazły się lubelskie, warmińsko-mazurskie, opolskie, podlaskie i świętokrzyskie. Zaproponowany podział nie jest precyzyjny, gdyż opiera się na wartościach bezwzględnych i nie bierze pod uwagę ani liczby ludności, ani potencjału gospodarczego poszczególnych województw.

Handel zagraniczny wykorzystywano też jako miernik w opracowaniach Instytutu Badań nad Gospodarką Rynkową. Przyjęto tam, że obecne zróżnicowanie wymiany towarowej regionów określi w znacznym stopniu ich przyszłą reakcję na akcesję (Profil wrażliwości..., 2003). Innymi słowy regiony o silnych więzach handlowych i korzystnej strukturze eksportu bardziej na akcesji skorzystają. Wszystkie wymienione prace wykonywane były w ujęciu dawnych lub obecnych województw. Pierwsze badania powiązań eksportowych na poziomie powiatowym przeprowadził T. Komornicki (2003) przy okazji ogólnej analizy międzynarodowych powiązań społeczno-gospodarczych polskich regionów. W niniejszym opracowaniu wykorzystano niektóre elementy tych studiów. 


\section{PODSTAWOWE CHARAKTERYSTYKI EKSPORTOWE}

\section{Bezwzględna wartość eksportu}

Rozpoczynając badania z zakresu geografii eksportu stajemy przed koniecznością dokonania wyboru miary podstawowej. Może nią być waga lub wartość wywożonych towarów. W przeszłości wiele opracowań wykorzystywało pierwszą miarę (ujęcie takie można umownie nazwać „transportowym” - waga miała kluczowe znaczenie z punktu widzenia fizycznego przewiezienia towarów do kraju docelowego). Obecnie duża waga wywożonych towarów świadczy o tradycyjnej oraz mało rozwojowej strukturze eksportu i najczęściej oznacza znaczny udział surowców mineralnych. Tym samym jedynym możliwym rozwiązaniem jest wykorzystanie w badaniach wartości wywożonych towarów (wyrażonej najczęściej w USD). Analiza rozkładu przestrzennego eksportu w wartościach bezwzględnych stanowi niezbędne tło przy tworzeniu wszystkich innych wskaźników. Sama w sobie charakteryzuje jednak przede wszystkim ogólne korzyści, jakie z eksportu może osiąnąć dany region. Aby przyjrzeć się bliżej roli tegoż eksportu w lokalnej gospodarce, konieczne jest odniesienie jego wartości do potencjału demograficznego oraz ekonomicznego (w tym przede wszystkim przemysłowego).

Polska odznacza się bardzo nierównomiernym rozkładem wewnętrznym handlu zagranicznego wyrażonego w wartościach bezwzględnych. Nierównomierność ta widoczna jest już w układzie wojewódzkim (dwie spośród 16 jednostek, mazowieckie i śląskie, skupiają 35,4\% eksportu; patrz tab. 1), a z całą mocą ujawnia się przy analizie przestrzennej na poziomie powiatowym. Wymiana towarowa $\mathrm{z}$ zagranica, a przede wszystkim eksport, skupia się w szeroko rozumianej zachodniej połowie kraju, gdzie w wymianie uczestniczą praktycznie wszystkie powiaty (ryc. 1). Jednocześnie w Polsce wschodniej handel prowadzony jest prawie wyłącznie w największych ośrodkach. Głównymi obszarami koncentracji eksportu w skali kraju są: (a) aglomeracja warszawska (ponad 11\% wartości eksportu, siedziba wielu firm handlowych, dominacja w eksporcie w prawie wszystkich branżach przemysłowych), (b) Górnośląski Okręg Przemysłowy (wraz z Okręgiem Bielskim; wywóz węgla, wyrobów przemysłu metalurgicznego oraz samochodów osobowych fabryki koncernów Fiat i General Motors), (c) LegnickoGłogowski Okręg Miedziowy (LGOM, wywóz miedzi), (d) aglomeracja poznańska (podobnie jak w Warszawie siedziba wielu firm handlowych, a ponadto eksport wyrobów przemysłu elektromaszynowego), (e) pozostałe duże aglome-racje miejsko-przemysłowe, w tym przede wszystkim gdańska, wrocławska, szczecińska, łódzka i krakowska, (f) wybrane mniejsze ośrodki, w których zlokalizowane są nowoczesne zakłady przemysłowe (najczęściej z udziałem kapitału zagranicznego), jak np. Olsztyn (Michelin), Kwidzyn (International Paper Corp.), Piła (Philips), Gorzów Wielkopolski (Volkswagen).

\section{Wartość eksportu na 1 mieszkańca}

O ogólnym znaczeniu eksportu dla danego regionu informuje nas jego wartość przeliczona na 1 mieszkańca. Potencjalnie wielkość wskaźnika może być zniekształcona poprzez różnice demograficzne, w tym przede wszystkim różnice w strukturze wiekowej. W skali 
globalnej powoduje to np. relatywne zaniżenie wartości wskaźnika w tzw. krajach Trzeciego Świata, gdzie najczęściej i tak niewielkiemu eksportowi towarzyszy ogromny udział ludności w wieku przedprodukcyjnym (nie przyczyniającej się bezpośrednio do produkcji, a tym bardziej wywozu). Niewątpliwym walorem jest natomiast ogólnoświatowa porównywalność wskaźnika, zarówno w ujęciu krajowym jak też regionalnym.

Jeżeli w Polsce wielkość eksportu przeliczymy na 1 mieszkańca poszczególnych powiatów, okaże się, że dysproporcje regionalne są jeszcze większe niż dla wartości bezwzględnych. Wysokim poziomem wskaźnika charakteryzuje się Wielkopolska, Ziemia Lubuska, Dolny Śląsk, Pomorze, aglomeracja warszawska, pojedyncze powiaty (miasta) na Górnym Śląsku oraz pas od Tarnowa po Stalową Wolę (fragment przedwojennego Centralnego Okręgu Przemysłowego). Na wschodnim pograniczu, północnym Mazowszu oraz w rejonie Kielc i Radomia wartość wskaźnika jest najczęściej mniejsza od 250 USD, a w niektórych powiatach spada nawet poniżej 50 USD (poziom notowany w najuboższych krajach afrykańskich). Jest to po części efekt przejmowania towarów produkowanych na tym obszarze przez Warszawę (traktowaną zarówno jako finalny rynek zbytu, jak i jako pośrednik w handlu zagranicznym).

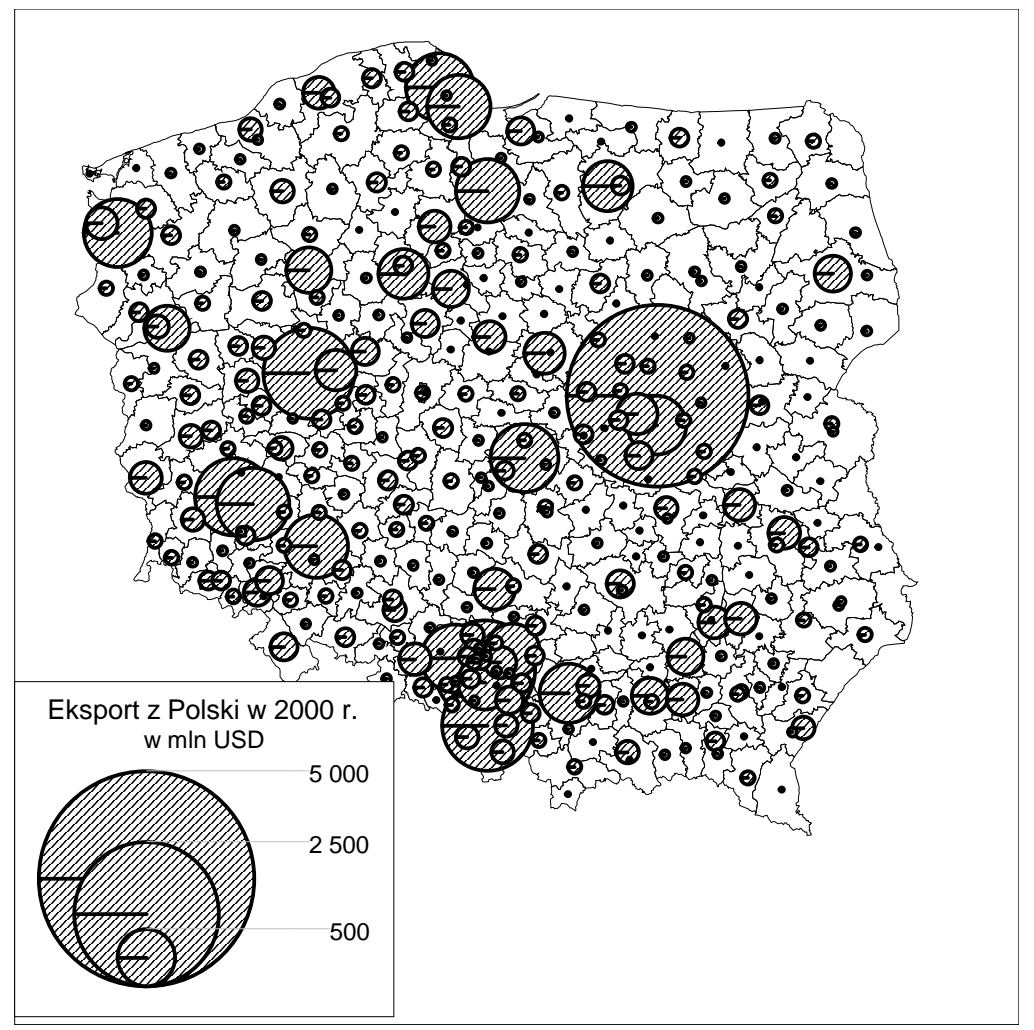

Ryc. 1. Eksport z Polski w 2000 r. wg powiatów

Źródło: opracowanie własne na podstawie materiałów CIHZ

Powiatem o zdecydowanie najwyższej wartości eksportu w przeliczeniu na 1 mieszkańca jest powiat polkowicki (miejsce eksploatacji rud miedzi). Ponadto wśród liderów w tym zakresie znalazły się siedziby spółek węglowych (Katowice), koncernów hutniczych 
(Dąbrowa Górnicza) i chemicznych (Police, Tarnobrzeg), dużych zakładów branży motoryzacyjnej (z kapitałem obcym; Bielsko-Biała i Tychy - FIAT, Gliwice - General Motors) oraz powiaty, do których sektora produkcyjnego napłynął znaczący kapitał zagraniczny (m.in. Kwidzyn - International Paper Corp., Piaseczno - Thomson, Piła - Philips, Gorzów Wielkopolski Volkswagen).

\section{Eksport względem PKB i produkcji sprzedanej przemysłu}

Wskaźnik wartości eksportu względem PKB lub produkcji sprzedanej przemysłu przedstawia obraz charakteru lokalnej gospodarki (lub produkcji przemysłowej), wskazując pośrednio, na ile jest ona proeksportowa. Porównanie z PKB może być dokonane wyłącznie na poziomie wojewódzkim. Odniesienie do produkcji przemysłowej można przeprowadzić także na poziomie powiatowym. Daje to oczywiście znacznie pełniejszy obraz sytuacji, a niekiedy pozwala na wskazanie konkretnych przedsiębiorstw przemysłowych determinujących wartość i strukturę wywozu z danej jednostki.

Tabela 1. Handel zagraniczny wg województw - wskaźniki podstawowe dla roku 2000

\begin{tabular}{|l|c|c|c|c|c|c|}
\hline Województwa & $\begin{array}{c}\text { Suma } \\
\text { całkowita } \\
\text { mln USD }\end{array}$ & $\begin{array}{c}\text { Udział } \\
\text { w eksporcie } \\
\text { Polskim } \\
\text { w \% }\end{array}$ & $\begin{array}{c}\text { na 1 miesz- } \\
\text { kańca } \\
\text { w USD }\end{array}$ & $\begin{array}{c}\text { Względem } \\
\text { PKB } \\
\text { w \% }\end{array}$ & $\begin{array}{c}\text { Udział } \\
\text { Unii Euro- } \\
\text { pejskiej } \\
\text { w \% }\end{array}$ & $\begin{array}{c}\text { Srednia cena } \\
\text { wyekspor- } \\
\text { kowanej } \\
\text { tony } \\
\text { w USD }\end{array}$ \\
\hline Dolnośląskie & 3386,0 & 10,7 & 1139 & 27,7 & 58,7 & 1429 \\
\hline $\begin{array}{l}\text { Kujawsko- } \\
\text {-pomorskie }\end{array}$ & 1409,1 & 4,5 & 671 & 18,9 & 80,8 & 887 \\
\hline Lubelskie & 762,3 & 2,4 & 342 & 12,2 & 75,5 & 374 \\
\hline Lubuskie & 1092,1 & 3,5 & 1066 & 29,3 & 54,7 & 406 \\
\hline Łódzkie & 1289,6 & 4,1 & 488 & 13,3 & 86,0 & 1200 \\
\hline Małopolskie & 1503,0 & 4,8 & 465 & 13,0 & 70,8 & 772 \\
\hline Mazowieckie & 5713,2 & 18,1 & 1126 & 18,8 & 58,9 & 801 \\
\hline Opolskie & 554,0 & 1,8 & 511 & 15,2 & 55,3 & 260 \\
\hline Podkarpackie & 1262,0 & 4,0 & 593 & 20,2 & 81,4 & 1378 \\
\hline Podlaskie & 413,2 & 1,3 & 338 & 11,6 & 53,0 & 1441 \\
\hline Pomorskie & 2673,3 & 8,5 & 1216 & 30,1 & 55,4 & 910 \\
\hline Śląskie & 5474,5 & 17,3 & 1129 & 25,4 & 70,3 & 173 \\
\hline Świętokrzyskie & 315,4 & 1,0 & 238 & 7,6 & 75,5 & 732 \\
\hline $\begin{array}{l}\text { Warmińsko- } \\
\text {-mazurskie }\end{array}$ & 860,3 & 2,7 & 586 & 18,9 & 70,0 & 1430 \\
\hline Wielkopolskie & 3353,5 & 10,6 & 998 & 23,7 & 68,9 & 1638 \\
\hline $\begin{array}{l}\text { Zachodnio- } \\
\text { pomorskie }\end{array}$ & 1497,5 & 4,7 & 864 & 21,5 & 83,0 & 365 \\
\hline nieustalone & 28,4 & 0,1 & $X X X$ & $X X X$ & 70,7 & 1169 \\
\hline POLSKA & $\mathbf{3 1 ~ 5 8 7 , 3}$ & $\mathbf{1 0 0 , 0}$ & $\mathbf{8 1 7}$ & $\mathbf{2 0 , 4}$ & $\mathbf{7 0 , 1}$ & $\mathbf{4 9 4}$ \\
\hline
\end{tabular}

Źródło: opracowanie własne na podstawie materiałów Centrum Informatyki Handlu Zagranicznego w Warszawie 
Województwami o najwyższym udziale eksportu w PKB są (patrz tab. 1): pomorskie (30,1\%), lubuskie i dolnośląskie. Zdecydowanie najniższe znaczenie wywozu dla całej gospodarki regionalnej obserwujemy natomiast w świętokrzyskim (zaledwie 7,6\%), podlaskim, lubelskim, łódzkim i małopolskim. W ujęciu powiatowym (patrz ryc. 2), jako wyraźnie nastawiony na eksport ukazuje się nam przemysł całej Polski zachodniej i północno-zachodniej, a w mniejszym stopniu także południowo-wschodniej. Rozkład jest więc podobny do tego, jaki uzyskaliśmy analizując eksport odnoszony do liczby ludności. Wyraźnie lepszą pozycję w zakresie proeksportowości gospodarki niż wielkości eksportu na 1 mieszkańca zanotowano jedynie w Polsce południowo-wschodniej. Potwierdza to tezę, że obraz potencjału handlowego regionu jest zaniżany przez odmienną strukturę demograficzną (większy odsetek osób w wieku przedprodukcyjnym). Najniższe wartości współczynnika (poniżej 15\%, a niekiedy nawet poniżej 10\%) nie występują już na całym pograniczu wschodnim, a jedynie w środkowej jego części. Jednostki z takimi wartościami grupują się natomiast na północnym Mazowszu i w woj. świętokrzyskim. Tym samym można sądzić, że niski poziom eksportu na wschodzie wiąże się z generalnie niższym poziomem produkcji, podczas gdy w niektórych regionach Polski centralnej jest efektem produkcji głównie na rynek krajowy.

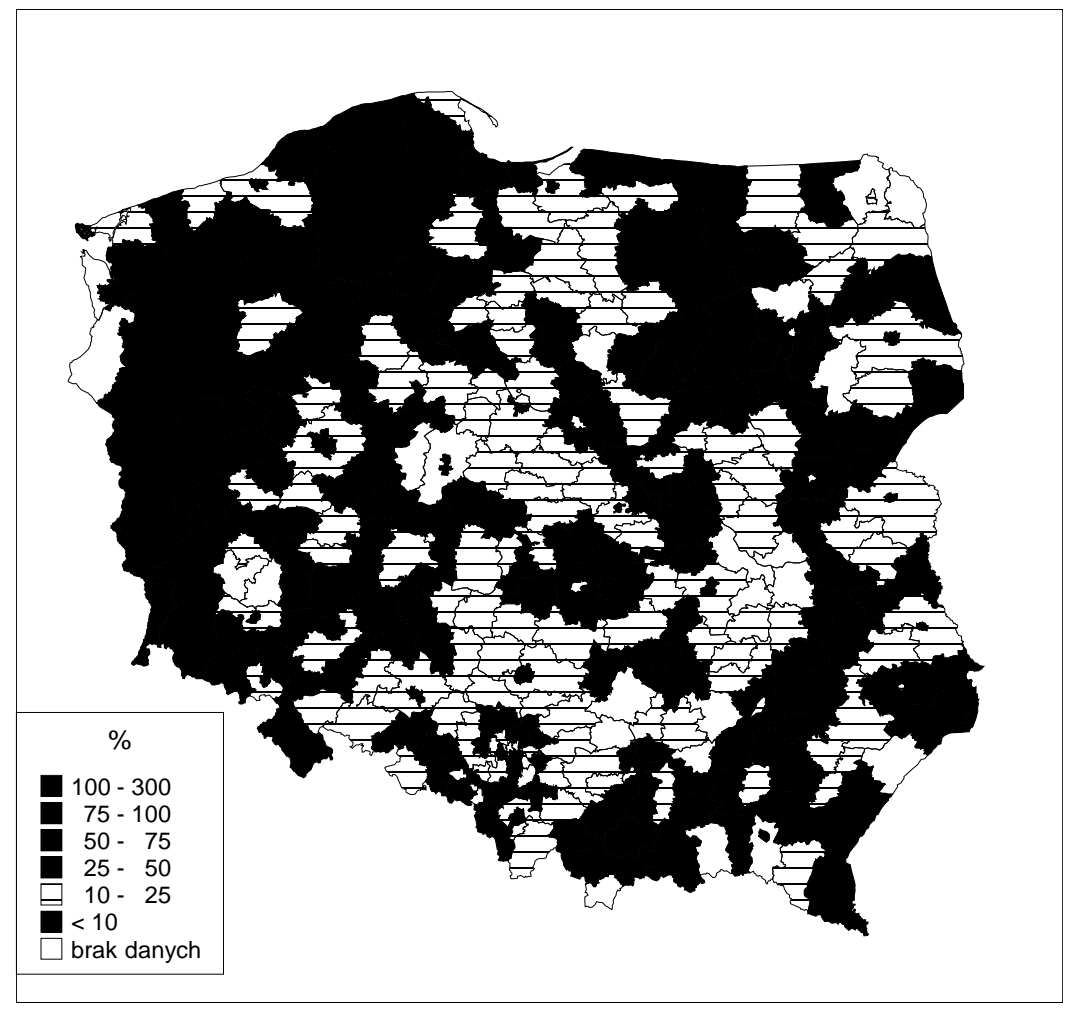

Ryc. 2. Eksport jako procent produkcji sprzedanej przemysłu w 2000 r. wg powiatów Źródło: opracowanie własne na podstawie materiałów CIHZ

W przypadku, jedynego w skali kraju, przygranicznego powiatu przemyskiego wystąpiła wyjątkowa sytuacja, w której wartość eksportu blisko trzykrotnie przewyższała wielkość produkcji sprzedanej miejscowego przemysłu. Wiąże się to z działaniem wielu firm 
eksportowych operujących na rynku ukraińskim. Może to też być przejawem funkcjonowania szarej strefy gospodarki, w ramach której odbywa się część produkcji (podczas gdy eksport podlega większej kontroli i tym samym jest ewidencjonowany). Pomijając przypadek powiatu przemyskiego, najwyższy poziom współczynnika (blisko 88\%) zanotowano w Katowicach (wywóz węgla wydobywanego w kopalniach całego Górnośląskiego Okręgu Przemysłowego). Ponadto w grupie liderów znalazły się ponownie powiaty z dużymi inwestycjami zagranicznymi, a także niektóre jednostki z Polski zachodniej o generalnie niewielkim potencjale przemysłowym, wykorzystywanym jednak głównie na potrzeby eksportu do Niemiec (np. pyrzycki, świdwiński, strzelecko-drezdenecki). W przypadku dużych aglomeracji polifunkcyjnych wartość wskaźnika była zdecydowanie mniejsza, co jest konsekwencją dużego rynku wewnętrznego.

\section{Struktura branżowa eksportu i stopień przetworzenia eksportowanych towarów}

Analiza struktury branżowej eksportu na poziomie regionalnym jest możliwa jedynie według głównych grup towarów (w klasyfikacji PCN lub SITC). Jest to przydatne przy charakterystyce sytuacji poszczególnych szeroko rozumianych branż przemysłowych. Jednocześnie jednak należy pamiętać, że podział na główne branże nie pozwala na jednoznaczne wyodrębnienie gałęzi zaawansowanych technologicznie (jako artykuły przemysłu chemicznego zakwalifikowane będą zarówno produkty „wielkiej chemii” jak i farmaceutyki najnowszej generacji). W tej sytuacji można przyjąć umownie, że o stopniu przetworzenia świadczy wartość (w USD) eksportu odniesiona do wagi (w tonach) wywożonych towarów. Wysoki poziom wskaźnika oznacza najczęściej wywóz produktów zaawansowanych technologicznie, a niski odpowiada eksportowi surowców mineralnych, względnie płodów rolnych lub drewna. Jednym z wyjątków od tak przyjętego założenia jest jednak np. produkcja i wywóz statków (co skutkuje niskim poziomem wskaźnika w miastach, w których zlokalizowane są stocznie). Wyjątkiem innego rodzaju jest tzw. eksport przerobowy odzieży, kiedy ubrania są szyte w Polsce wg wzorów i z materiałów pochodzących z zagranicy (Wieloński 2000).

Zróżnicowanie regionalne współczynnika odbiega dość znacznie od zróżnicowania występującego w przypadku trzech omówionych wyżej charakterystyk. W ujęciu wojewódzkim w 2000 r. (tab. 1) najwyższa był cena tony wyeksportowanej z wielkopolskiego, dolnośląskiego, podlaskiego, warmińsko-mazurskiego i podkarpackiego; najniższa ze śląskiego i lubelskiego, lubuskiego i zachodniopomorskiego. Na poziomie powiatowym (ryc. 3) widzimy, że szeroko rozumiana Polska północno-zachodnia odznacza się tym razem wyraźnie słabszą pozycją. Dotyczy to w szczególności położonych na tym terenie powiatów ziemskich. W prawie wszystkich powiatach graniczących z Niemcami (gdzie, jak pamiętamy, rola eksportu tak ogółem jak i do krajów Unii jest relatywnie bardzo duża) średnia wartość wyeksportowanej tony nie przekracza 500 USD. Bardzo niska jest ona także w całym zachodniopomorskim. Zdecydowanie niskimi wartościami wskaźnika odznaczają się prawie wszystkie miasta Górnego Śląska. Na pozostałym obszarze kraju obraz przestrzenny ma charakter mozaikowy. Niska cena średniej wywożonej tony w wielu regionach o dużej roli eksportu dowodzi ekstensywnego charakteru prowadzonej wymiany. Można domniemywać, że koniunktura gospodarcza na tych obszarach jest silnie uzależniona od cen surowców i towarów słabo przetworzonych (np. drewna) na rynkach europejskich. 


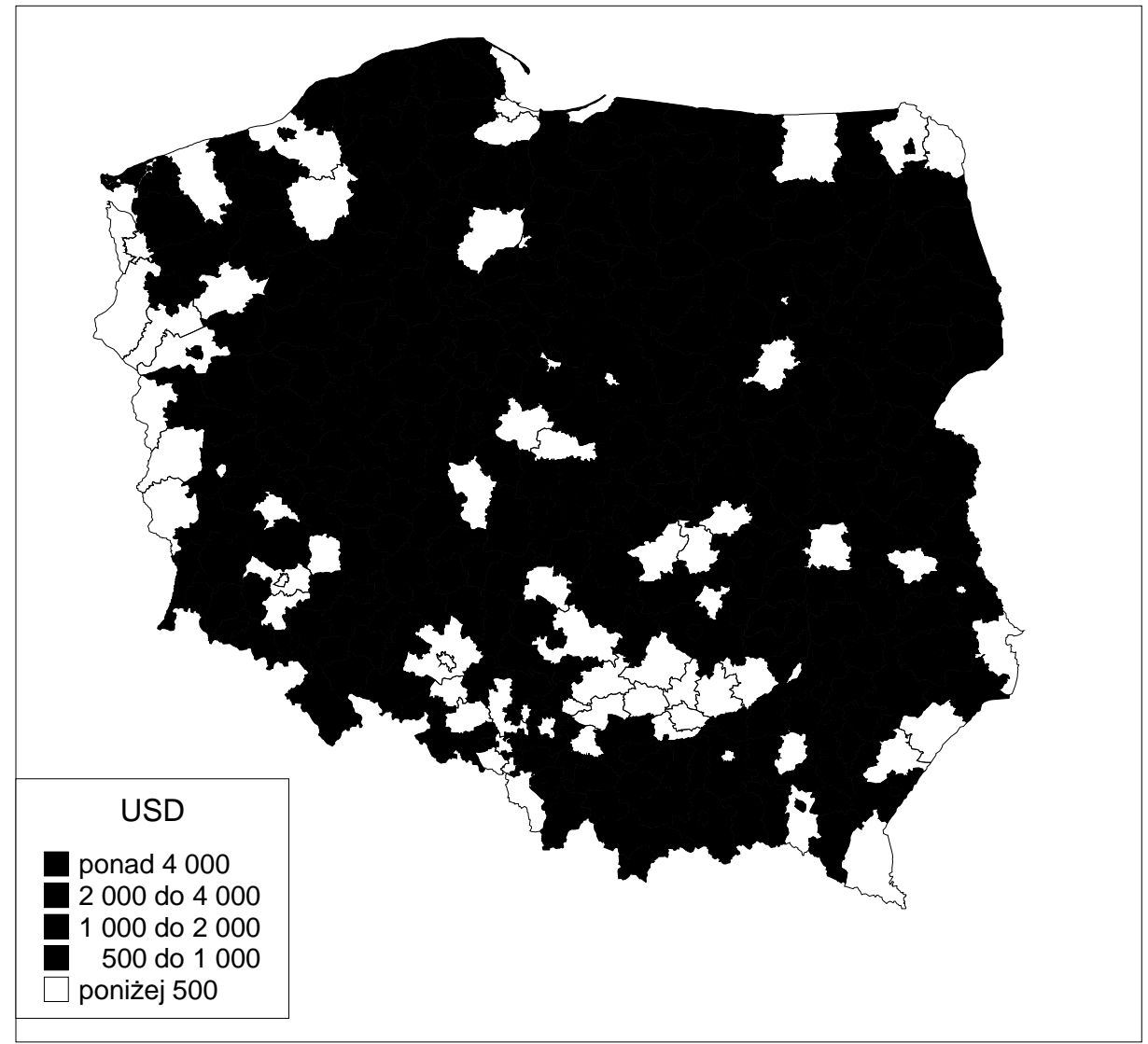

Ryc. 3. Średnia cena 1 wyeksportowanej tony w 2000 r. wg powiatów Źródło: opracowanie własne na podstawie materiałów CIHZ

Najwyższą wartość mają towary wywożone z powiatu kolneńskiego w województwie podlaskim (10,7 tys. USD; zakłady firmy Bison-Bial, należącej do największych na świecie producentów oprzyrządowania technologicznego obrabiarek, były w 2000 r. prawdopodobnie jedynym istotnym eksporterem). Ponadto wysokie wartości zanotowano w niektórych ośrodkach inwestycji zagranicznych. Poza będącymi siedzibami FIAT-a Bielska-Białej i Tychami, nie są to jednak najczęściej ośrodki największe. Relatywnie dobrze wypadły też ośrodki przemysłu lekkiego (w tym Łódź). Można sądzić, że wśród liderów znalazły się raczej powiaty, w których obok głównego eksportera (produkującego towary o relatywnie wyższej wartości) brak jest innych firm, zaniżających średnią wartość eksportowanej tony poprzez wywóz towarów mało przetworzonych. Bardziej jednorodną grupę stanowią natomiast powiaty o najmniejszym stopniu przetworzenia wyrobów eksportowanych. Są to siedziby spółek węglowych, ośrodki przemysłu cementowego, niektórych branż przemysłu chemicznego oraz regiony eksportu drewna i płodów rolnych. 


\section{Struktura kierunkowa eksportu}

Struktura kierunkowa eksportu świadczy pośrednio o konkurencyjności produkcji przemysłowej na rynkach międzynarodowych. Duży udział tzw. rynków wymagających (Unia Europejska, a także inne kraje OECD) jest dowodem na konkurencyjność jakościową lub cenową wytwarzanych towarów. Może więc być przejawem zarówno zaawansowania technologicznego, jak i niskich kosztów produkcji (lub faktu jej dotowania). W Polsce mamy do czynienia z obydwoma wymienionymi sytuacjami. Jednocześnie jako przejaw korzystnej sytuacji, zarówno w samym eksporcie, jak i w zakresie rozwoju przemysłowego regionu, uznać należy wysoki poziom dywersyfikacji partnerów zagranicznych. Zabezpiecza on przed skutkami sytuacji kryzysowych na poszczególnych rynkach zagranicznych (w przypadku Polski przede wszystkim na rynku niemieckim, ale po części także na rynkach byłego Związku Radzieckiego).

Na przeważającej części obszaru kraju dominuje handel z 15 krajami obecnej Unii Europejskiej. Duże różnice regionalne występują jednak w udziale eksportu do Unii w stosunku do całej jego wartości. Układ przestrzenny jest w przypadku tego wskaźnika niezwykle przejrzysty. Znaczenie Unii w eksporcie maleje stopniowo w miarę przesuwania się ku wschodowi, na rzecz większego udziału wywozu do państw byłego ZSRR.

Jednostką, z której eksport w największym stopniu $(99,8 \%)$ trafia na rynek 24 państw przyszłej, poszerzonej Unii Europejskiej, jest ponownie produkujący miedź powiat polkowicki. Wartości wskaźnika przekraczające 99\% zanotowano jednak łącznie w 8 powiatach, przekraczające $90 \%$ w 144, a przekraczające $80 \%$ aż w 255 jednostkach. $Z$ drugiej strony udział tak rozumianego rynku europejskiego był w 2000 r. mniejszościowy tylko w 21 powiatach. Poziom dywersyfikacji partnerów jest $\mathrm{z}$ reguły większy $\mathrm{w}$ dużych aglomeracjach (szczególnie warszawskiej, górnośląskiej i gdańskiej), a ponadto wzrasta on ku wschodowi, gdzie obok rynków europejskich znacząca rolę odgrywają partnerzy $\mathrm{z}$ byłego ZSRR (a w przypadku niektórych ośrodków przemysłowych województwa podkarpackiego także ze Stanów Zjednoczonych). Prawie wszystkie powiaty o mniejszościowym udziale rynków poszerzonej Unii skoncentrowane są w województwach wschodnich.

\section{PRZESTRZEŃ EKSPORTOWA A PRZESTRZEŃ PRZEMYSŁOWA POLSKI}

Interesującym zagadnieniem badawczym jest odniesienie charakterystyk eksportowych do przestrzeni przemysłowej kraju. Obliczenie wskaźników dla wyodrębnionych metodą tradycyjną okręgów przemysłowych pozwala na stwierdzenie, na ile są one elementem międzynarodowej przestrzeni gospodarczej, a tym samym pośrednio na ich ocenę jakościowa. $\mathrm{W}$ tab. 2 przedstawiono współczynniki obliczone dla 15 okręgów przemysłowych wydzielonych przez W. Gierańczyk i A. Stańczyka (2001). Ogólna koncentracja eksportu na obszarze okręgów okazała się nieznacznie większa niż koncentracja produkcji przemysłowej (odpowiednio 54,9\% i 52,4\% wartości dla całej Polski). O międzynarodowym znaczeniu poszczególnych okręgów świadczą relatywnie duże różnice punktowe na korzyść udziału 
Tabela 2. Wskaźniki eksportowe w okręgach przemysłowych* Polski

\begin{tabular}{|c|c|c|c|c|c|c|c|}
\hline \multirow[b]{2}{*}{$\begin{array}{c}\text { Okręgi } \\
\text { przemysłowe }\end{array}$} & \multicolumn{3}{|c|}{ Udział Okręgu w: } & \multirow[b]{2}{*}{$\begin{array}{l}\text { Eksport } \\
\text { na } 1 \\
\text { miesz- } \\
\text { kańca }\end{array}$} & \multirow[b]{2}{*}{$\begin{array}{l}\text { Udział Unii } \\
\text { Europejskiej } \\
\text { w eksporcie }\end{array}$} & \multirow[b]{2}{*}{$\begin{array}{c}\text { Eksport } \\
\text { jako \% } \\
\text { produkcji } \\
\text { sprzedanej }\end{array}$} & \multirow[b]{2}{*}{$\begin{array}{c}\text { Średnia } \\
\text { cena } 1 \\
\text { wyeks- } \\
\text { portowa- } \\
\text { nej tony } \\
\text { w USD }\end{array}$} \\
\hline & $\begin{array}{l}\text { liczbie } \\
\text { ludności }\end{array}$ & $\begin{array}{l}\text { produkcji } \\
\text { sprzeda- } \\
\text { nej } \\
\text { przemy- } \\
\text { słu }\end{array}$ & $\begin{array}{l}\text { wartości } \\
\text { eksportu }\end{array}$ & & & & \\
\hline Bielski & 2,5 & 3,9 & 4,8 & 1565 & 82,4 & 37,3 & 1772 \\
\hline Bydgoski & 1,0 & 1,3 & 1,3 & 1025 & 70,8 & 28,9 & 1892 \\
\hline $\begin{array}{l}\text { Dębicko- } \\
\text { Stalowowlski }\end{array}$ & 1,3 & 1,9 & 2,3 & 1453 & 51,1 & 36,5 & 1734 \\
\hline Gdański & 1,9 & 3,0 & 4,0 & 1667 & 58,0 & 40,9 & 690 \\
\hline Kaliski & 0,9 & 1,0 & 0,6 & 529 & 70,0 & 18,7 & 1648 \\
\hline Krakowski & 1,9 & 2,7 & 1,6 & 671 & 63,3 & 18,2 & 926 \\
\hline Lubelski & 1,1 & 0,8 & 0,8 & 569 & 50,8 & 30,0 & 1606 \\
\hline Łódzki & 3,3 & 3,4 & 2,5 & 636 & 67,8 & 22,7 & 2533 \\
\hline Poznański & 2,5 & 4,4 & 4,8 & 1576 & 82,6 & 33,7 & 2349 \\
\hline Szczeciński & 1,2 & 1,3 & 2,6 & 1723 & 57,5 & 62,2 & 351 \\
\hline Śląski & 8,9 & 13,0 & 12,5 & 1143 & 72,0 & 29,6 & 129 \\
\hline Świętokrzyski & 0,8 & 0,6 & 0,2 & 207 & 70,9 & 10,2 & 691 \\
\hline Wałbrzyski & 1,1 & 0,7 & 1,0 & 793 & 77,4 & 43,0 & 956 \\
\hline Warszawski & 5,7 & 12,7 & 14,4 & 2067 & 54,1 & 35,0 & 822 \\
\hline Wrocławski & 1,6 & 1,7 & 1,8 & 872 & 67,2 & 31,7 & 995 \\
\hline $\begin{array}{l}\text { Okreggi } \\
\text { przemysłowe } \\
\text { razem }\end{array}$ & 35,7 & 52,4 & 54,9 & 1257 & 65,8 & 32,3 & 389 \\
\hline POLSKA & 100,0 & 100,0 & 100,0 & 817 & 70,1 & 30,8 & 494 \\
\hline
\end{tabular}

*delimitacja przyjęta za Gierańczyk, Stańczyk 2001

Źródło: opracowanie własne na podstawie materiałów Centrum Informatyki Handlu Zagranicznego w Warszawie

w eksporcie. Sytuacja taka miała w 2000 r. miejsce w okręgach warszawskim, bielskim, gdańskim i szczecińskim. Jednocześnie jako mało eksportowe (zauważalnie mniejszy udział w eksporcie niż w produkcji sprzedanej) ujawniły się okręgi krakowski, łódzki (po części prawdopodobnie z uwagi na duży udział eksportu „walizkowego”), świętokrzyski i kaliski. Eksport przeliczony na 1 mieszkańca był we wszystkich okręgach ogółem przeciętnie wyższy niż średnio w kraju. W kilku konkretnych okręgach był jednak zaskakująco niski (zwłaszcza w staropolskim). Jest charakterystyczne, że udział Unii Europejskiej w całości eksportu okazał się w okręgach przemysłowych niższy niż średnio w kraju. Można to traktować jako dowód, że na rynkach europejskich funkcjonują często małe i średnie przedsiębiorstwa z mniejszych ośrodków, podczas gdy duże firmy reprezentujące tradycyjne gałęzie przemysłu mają tam problemy ze zbytem swoich wyrobów. Najwyższy udział Unii zanotowano w okręgach wielkopolskim i bielskim, zdecydowanie najniższy w warszawskim, łódzkim i dębicko-stalowolskim.

Współczynnikiem bezpośrednio charakteryzującym rolę eksportu w poszczególnych okręgach jest udział wartości wywozu w produkcji sprzedanej. Najwyższy jest on w okrę- 
gach: szczecińskim (aż 62,2\%), wałbrzyskim, gdańskim, dębicko-stalowowolskim i bielskim; bardzo niski w świętokrzyskim (10,2\%), kaliskim i krakowskim. Okręgi różnią się też znacznie pod względem średniej ceny 1 wyeksportowanej tony. Z uwagi na wywóz węgla kamiennego w okręgu śląskim cena ta wynosi tylko 129 USD. Niska jest także w szczecińskim, gdańskim (wywóz statków) i świętokrzyskim. Najbardziej przetworzona wydaje się być natomiast produkcja eksportowa z okręgów łódzkiego (odzież), poznańskiego, bydgoskiego, bielskiego i dębicko-stalowowolskiego.

\section{PODSUMOWANIE}

Przeprowadzona analiza potwierdziła przydatność wskaźników eksportowych w badaniach z zakresu szeroko rozumianej geografii społeczno-ekonomicznej, w tym geografii przemysłu. Stwierdzono, że o wielkości eksportu w dużej mierze decyduje nowoczesny potencjał przemysłowy. Dodatkowa koncentracja wywozu w Warszawie i innych dużych aglo-meracjach wynika nie tyle z ich potencjału demograficznego, co ze znacznych zasobów tzw. kapitału ludzkiego (w tradycyjnej nomenklaturze wykształconej siły roboczej) oraz z umiejscowienia w nich ośrodków władzy (sprzyjającej lokalizacji siedzib dużych przedsiębiorstw). Jeżeli zatem pominiemy największe ośrodki oraz tradycyjne zagłębia surowcowe, okaże się, że wielkość eksportu w znacznym stopniu nawiązuje do rozmieszczenia inwestycji zagranicznych w sferze produkcji. Dodatkowym czynnikiem jest rozmieszczenie rodzimej drobnej przedsiębiorczości. Jest to widoczne przede wszystkim w Polsce zachodniej (pogranicze niemieckie), gdyż na wschodzie najprawdopodobniej umyka statystyce oficjalnej pozostając w szarej strefie (eksport nierejestrowany).

Przeprowadzone porównanie przestrzeni przemysłowej i eksportowej Polski prowadzi do dwóch podstawowych wniosków. Po pierwsze, tylko część wyodrębnionych okręgów przemysłowych ma charakter eksportowy. W przypadku największych aglomeracji nieco mniejsze znaczenie wywozu zagranicę można przy tym tłumaczyć wielkością rynku lokalnego (choć różnice pomiędzy aglomeracjami przemawiają zdecydowanie na korzyść Warszawy, Poznania, Wrocławia i Gdańska oraz na niekorzyść Górnego Śląska, Łodzi i Krakowa). W odniesieniu do okręgów pozagalomeracyjnych trzeba natomiast przyjąć, że niewielka rola eksportu dowodzi ich słabej pozycji ekonomicznej. Do ,,przestrzeni eksportowej” nie należy na pewno okręg świętokrzyski i najprawdopodobniej kaliski. Drugim istotnym wnioskiem jest większe rozproszenie konkurencyjnego eksportu w porównaniu do tradycyjnie wyodrębnianej (za pomocą wielkości zatrudnienia) przestrzeni przemysłowej. Dowodzi tego mniej korzystna struktura kierunkowa eksportu oraz niższy stopień przetworzenia wywożonych towarów, jaki obserwujemy w obrębie okręgów przemysłowych (względem średniej krajowej). Można to rozumieć jako potwierdzenie tezy A. Wielońskiego (1998), że za źródło dynamiki gospodarczej i konkurencyjności uznać należy w Polsce renesans przemysłu drobnego. 


\section{Literatura}

Gierańczyk W., Stańczyk A., 2001, Okręgi przemystowe w Polsce u progu XXI wieku, [w:] Problemy przemian struktur przemystowych $w$ procesie wdrażania regut gospodarki rynkowej, red. Z. Zioło, Prace Komisji Geografii Przemysłu PTG, nr 3, Warszawa-Kraków-Rzeszów, s. 61-70

Grabowiecki J., 2001, Wymiana handlowa, [w:] Województwo podlaskie u progu XXI wieku, red. R. Horodeński, C. Sadowska-Snarska, Wydawnictwo Wyższej Szkoły Ekonomicznej, Białystok, s. 341-350

Komornicki T., 2000, Potoki towarowe polskiego handlu zagranicznego a międzynarodowe powiazania transportowe, Prace Geograficzne, 177, IGiPZ PAN, Warszawa

Komornicki T., 2003, Przestrzenne zróżnicowanie międzynarodowych powiazań społeczno-gospodarczych $w$ Polsce, Prace Geograficzne, 190, IGiPZ PAN, Warszawa

Profil wrażliwości gospodarki regionalnej na integrację z Uniq Europejska - Województwo mazowieckie, 2003, red. S. Umiński, Instytut Badań nad Gospodarką Rynkową, Gdańsk

Rössner T., Anisimowa G., Komornicki T., Miros K., Röttger A., 1998, Die Miteleuropäische West-OstAchse Sachsen-Schlesien-Galizien, Daten, Fakten, Literatur zur Geographie Europas 5, Institut für Landerkunde, Leipzig

Rogacki H., 2001, Zróżnicowanie aktywności eksportowej i importowej województw Polski, [w:] Problemy przemian struktur przemystowych $w$ procesie wdrażania regut gospodarki rynkowej, red. Z. Zioło, Prace Komisji Geografii Przemysłu PTG, nr 3, Warszawa-Kraków-Rzeszów, s. 43-50

Stryjakiewicz T., 2002, Globalizacja i „nowa gospodarka” a dylematy geografii ekonomicznej”, [w:] Rozwój regionalny i lokalny a procesy globalizacji, red. B. Miszewska, M. Furmankiewicz, Przekształcenia regionalnych struktur funkcjonalno-przestrzennych, 6, Uniwersytet Wrocławski, Wrocław, s. 9-16

Wieloński A., 1998, Od industrializacji do reindustrializacji, WGiSR, Uniwersytet Warszawski, Warszawa

Wieloński A., 2000, Geografia przemystu, PWN, Warszawa

Wnorowski H., 2002, Międzynarodowe uwarunkowania procesów rozwojowych regionów, [w:] Problemy rozwoju przygranicznych regionów wschodniej Polski, red. C. Sadowska-Snarska, Wydawnictwo Wyższej Szkoły Ekonomicznej w Białymstoku, Białystok, s. 49-60 